\title{
Gang culture, Identity and Kaaps: Using Adam Small's Krismis van Map Jacobs in Cape Flats schools
}

\author{
Michael le Cordeur \\ Stellenbosch University
}

Correspondence to: mlecorde@sun.ac.za

\begin{abstract}
In this paper the focus is on the impact of gang culture on schoolchildren. The research question investigated here is whether teaching the drama Krismis van Map Jacobs offers any solutions to learners in gang-infested areas, given the framework of the Curriculum Assessment Policy Statement (CAPS). Two sub-questions considered whether the teaching of the drama should take place in Kaaps and whether the theme of Map Jacobs is still relevant within the CAPS curriculum 30 years after it was written by Adam Small. Theoretically, the paper is based on Pierre Boudieu's (1991) view that a speaker's 'position' in society determines whether he is heard, Bernstein's (1990) idea that social interaction influences your relationship with language and Vygotsky's (1978) theory of social constructivism. The study concludes that a life with gangs provides no solution for issues like poverty and unemployment, and that the youth should escape from a featureless existence through striving for good education and engaging with literature. The paper is published with the kind permission of the SA Academy for Science and the Arts, as it originally appeared in the book Adam Small: Denker, Digter, Dramaturg; 'n Huldingingsbundel (2017, SAWK).
\end{abstract}

\section{INTRODUCTION}

Nou het 'n Moses vir julle opgestaan. [Now a Moses has arisen for you.]

- 'Exodus' from Kitaar my kruis

Adam Small was a philosopher and a prophet: the voice of the voiceless. This is the conclusion Carstens and Le Cordeur come to in the foreword of the book Ons kom van vêr (2016).
At the time when his people were moved out their homes and neighbourhoods by force, he expressed their pain. By writing in Kaaps, he empowered them linguistically and so gave his people their voice back which had been silenced by the establishment, media and apartheid government (Le Cordeur 2014). Thus he placed himself and his future on the altar. Small's reference to Moses who led his people 
out of the desert of apartheid to the promised land of true democracy must also be read in this context (Le Cordeur 2016c).

Willemse (2016) calls Small an interpreter, the Moses-figure in his second collection Kitaar my kruis (1962). Steward van Wyk (Van Wyk 2012) also refers to the issue of identity. During the presentation of the Hertzog Prize to Small, Van Wyk mentioned in his motivation speech that Krismis van Map Jacobs is a thorough investigation of guilt and liability as well as issues of identity. According to Van Wyk, Map Jacobs is a victim of job reservation who then lapsed into the gang culture. In his tragic quest for identity he says:

... cause ek wil somewhere ge-belong het. Kan jy sien die merke (Apostel) George? Kan jy sien die tattoos? 'it was 'n terrible gesoek vir 'n identity ... (Small 1983: 31) [... 'cos I wanted to belong somewhere. Can you see the marks (Apostle) George? Can you see the tattoos? It was a terrible search for identity ...]

\section{A SOCIO-LITERARY PERSPECTIVE}

According to Van Wyk (2012), Adam Small did not hesitate to tackle broad, universal themes. This included social issues such as apartheid, poverty, love and reconciliation, as well as the ideals of ordinary people. Throughout, Small reflects a nuanced image of the community. In his dramas one finds a variety of outcast characters which add to the portrayal and the mood: vegetable and flower sellers, guitar players, a
Christmas band, aunties and uncles, gang members, vagrants and street preachers. This indicates his identification with the less privileged.

This paper reviews how Small approached this theme in his 1983 drama Krismis van Map Jacobs, a play which strongly delves into Small's experiences as a social worker. We relive the apartheid years. Mr Cavernelis is a decent man of modest means who wants to get his beautiful daughter, Blanchie, and his capricious second wife, Maud, out of the wasteland of the Cape Flats (Small: Krismis van Map Jacobs, 1983: 22; hereafter only the page numbers eg.: 22). It requires making money and he does not make enough at the polony factory, nor with the hawking of "petticoats en panties in sy suitcasie agter op sy alte fênsie fiets nie' (20) [hawking petticoats and panties in his little suitcase on the back of his very fancy bicycle]. The men who play kerrim (a local version of snooker) in the street, especially tough Cyril and his comrade Richie, say this 'haitie-taitie dêrre' ${ }^{1}$ uses Blanchie 'deur haar te laat werk in die massage parlour en vir die lonely hearts (20).' [this hoitytoity dad uses Blanchie by making her work in the massage parlour and for the lonely hearts.] But Mr Cavernelis must be careful, as Map is coming out of prison and 'ammal moet nou beginne cover-up' (22) [everyone must now start covering up].

Map is in prison for murder after he stabbed a member of his gang to death who, with other gangsters, raped Map's mother, Auntie Grootmeisie, and his sister. This terrible crime actually originated with an order given by Map as gang leader, who did not realise that his

1 Derre is Kaaps for Dedda or Daddy while "haitie-taitie" is Kaaps for "high and mighty". 
mother and sister would be the victims in question. After he surrendered to the police, a deeply remorseful and traumatized Map was sentenced to twelve years in prison, of which he served seven years.

Now he has received parole. The question is: What kind of person will he be by this time? (Cf. Botha 2015). The truth is that Map Jacobs, thanks to Apostle George, changed while he was in prison. George helped him to repent (30). When he gave Map (baptised Johnnie Jacobs) back to his mother, Auntie Grootmeisie, he said: 'There is your son, Missus Jacobs, after seven long years ... Sister, receive your son in the peace of God, take him back with you ...' (29)

The Cape Flats provides the background to the story of MapJacobs. In both the stage directions and sometimes also in the dialogue of the characters, the Cape Flats is portrayed as a vast sandy area far from the Cape Town city centre and its facilities. For example, the character Willy la Guma refers to the origin of the Cape Flats, how people were removed from places like District Six and Claremont to the Flats by force.

Maar wat gebeur? Group areas! The District Sixes, the Claremonts, the Simonstowns! You name it, mister Cavernelis. Hulle bulldoze vir jou simply ýt, ýt, yt jou eie bietjie history ýt. (51) [But what happened? The Group areas! The District Sixes, the Claremonts, the Simonstowns. You name it, Mr Cavernelis. They simply bulldozed you out, out, out of your own bit of history.]

He describes the bare sandy Cape Flats as a miserable place and a "wasteland" where the southeaster blows at its worst. When Blanchie and Map embrace at the end of the drama, a description of how the wind blows and continues to blow in the Cape Flats follows (Small 1983: 60). It is a place where no grass or flowers grow:

... en dan ... bou hulle vir jou hierdie council-flats, hierdie matchbox op match-box, hierso op die kaal Cape Flats sand, hierso waar die South Easter op sy worst waai ... Here, where flowers an' grass jus' don't grow ... (52) [ ... and then ... they build these council flats for you, these match-boxes upon matchboxes, here on the bare Cape Flats sand, here where the Southeaster blows at its worst ... Here where flowers and grass just don't grow...]

More specifically, the play takes place in the township, a neighbourhood on the Cape Flats. Typical of a township are the lively street scenes and street noise. It is still long before Christmas, but the Christmas band is already practising. There are kerrim players who have placed their board on a drum and Tommy Sobotker who hawks his little rings and bangles from a handcart. The streets are described as 'cement strips' by La Guma (Small 1983: 49).

There is talk of the 'flats and council houses' in which the people live, the blocks and blocks of grey flats typical of the Cape Flats. The Cavernelis family, for example, live in a 'flat', and Mr Cavernelis parks his bicycle on the small platform in front of it. Auntie Grootmeisie, Map's mother, lives in a council flat. The people try to allay the hopelessness of their existence by painting their little gray houses in bright colours and affixing bright motifs. For the community, the flats of course symbolise all the injustices done to them by the apartheid government. La Guma gestures to the flats and says this is what the 'vylgoed' [bastards] (the old 
government) had done to them. (Small 1983: 50 -52).

Eventually, many young men may head to prison, as was also the case with Map Jacobs. The drama describes the prison walls as gray with a sombre, depressing atmosphere. The thick glass which separates prisoners from visitors imprints the controlled, caged existence of the prisoner on the reader. In prison, Map Jacobs comes to realize that his life as gang leader was actually pointless, that he had acted cruelly, and he confesses his sin to the Lord:

Skullag en vuil en vieslik! Here, kan jy die merke sien, al die merke wat ek my laat merk het ...'n Vieslike Map. Van al die merke, al die tattoos, call hulle toe vir my Map Jacobs ... Apostel George, wat jy gestuur het, Here, hy's reg ... hy wiet waarnatoe om te gaan. (31) [Guilty and dirty and awful! Lord, do you see the marks, all the marks I had myself marked with ... An awful map. From all the marks, all the tattoos, they then called me Map Jacobs ... Apostle George, whom you sent, Lord, he is right ... he knows where to go.]

Map's imprisonment is really symbolic of a whole community's captivity because they experience the townships as prisons. Thus the whole township is actually a prison. Irony also plays a role. It is ironic that Map Jacobs returns after seven years in prison to an area which the residents experience as a prison - a dreary existence from which they wish to, but cannot, escape. Willy la Guma says ironically:

Nou is Map Jacobs terug ...Yt die tronk yt. Terug, hiernatoe. Kan jy dit vir jou imagine? Hiernatoe? Kamma yt die tronk yt. Na dit toe! (50) [Now Map Jacobs is back ...
Out of prison. Back here. Can you imagine that? Here? Supposedly out of prison. To this!]

It is especially Mr Cavernelis and his family - his wife, Maude, and daughter, Blanchie (Map's girlfriend) - who suffer criticism from the community. The gang member Cyril says:

Moenie so panic nie, ou Dad. Ons verstaan. Dink jy ons verstaan nie? Jy en die missies julle wil julle ytkoep hierso yt die township yt. Julle spaar mos vir 'n hys en 'n plotjie grond, somewhere else. In 'n decent Coloured area. Julle wil hier yt die township yt escape. Djulle fit mos nie in nie. Nie onse types nie. (22) [Don't panic, old Dad. We understand. Do you think we don't understand? You and the missus want to buy yourselves out of the township. You save for a house and a little plot of land, somewhere else, in a decent Coloured area. You want to escape the township, because you don't fit in. Not our type.]

The citation refers to the reality of the gang culture which is hard and merciless. The newspapers are full of reports about the violent environment and the police themselves get caught in the crossfire (see various media reports on Network 24 and others in the reference list.) It is also a life of poverty with all its appalling conditions of crime, robbery, rape and killing of innocent people. Some of these really awful conditions are reflected in the drama with the Cavernelis family's longing and need to escape from this world: 'Dis hoekom ek en Maud en Blanchie hierso wil weg!' (Small 1983: 50) [That is why Maud and Blanchie and I want to leave this!].

In La Guma's words it is only the most fortunate who get a 'lucky 
break' (50). Most people live under the breadline, which makes it difficult, actually impossible, to save enough to buy a house in 'a decent Coloured area' (22). Unless of course, like Blanchie and her father, you cross the boundaries of your own moral compass and make extra money by doing things which are contrary to your character and values.

Disillusionment strikes in the eleventh scene, when Blanchie receives a letter in which she is informed that the overseas modelling contract she applied for has not been awarded to her. She and Mr Cavernelis are aghast. This makes Blanchie and her people realize once again their powerlessness within the incarceration of the South African race dispensation. This shows the empty promises of the time, and that those who made the promises could not insist that they be fulfilled (Prins 1987: 36). Cavernelis's wife, Maud, puts the naked truth as follows:

... when they've used you, that's it ... Maar ek het vir jou gesê sweetheart, those white dandies, die klomp fashion-moffies ... hulle sil vir jou use tot lat hulle jou klaar ge-use het, en dan ... dump hulle vir jou ... (53) [... when they've used you, that's it ... But I told you, sweetheart, those white dandies, that bunch of fashion pansies ... they will use you until they have finished using you, and then ... they will dump you ...]

But life is not only pain and heartbreak. Even in the dreary existence of the township there is deliverance. Map repents in prison and asks for forgiveness: 'So God vergewe my' (35). Because he himself asks for forgiveness for his actions, it makes it possible for him also to forgive Blanchie, to the great surprise of the people in the neighbourhood: 'Lyster, julle almal!
Ek mind nie wat Blanchie gedoen het nie. Ek mind van niks.' (46) [Listen, everyone! I don't care what Blanchie did. I don't care about anything.]

The playwright used an effective metaphor to introduce the new Map Jacobs to the reader: 'Kyk hy het nuwe klere aan! Hy is skoon gewas ...' (29) [Look, he has new clothes on! $\mathrm{He}$ is washed clean ...]

Thanks to this forgiveness, he and Blanchie can continue their lives and can at last be happy. But it is only possible because Map has changed: 'Blanchie ... ek het shit aangevang ... ek was nie meer die ou wat jy op skool geken het nie ... maar nou, ek het weer ge-change, ek het weer mens geword ...' (47). [Blanchie ... I did shit things ... I wasn't the guy you knew at school anymore ... but now, I have changed again, I have become human again ...]

\section{A PROTEST DRAMA}

Coetser (in Willemse and Van Wyk 2012) refers to the thematic representations of 'passive and actual protest' in Small's dramas, including Krismis van MapJacobs, at the hand of theoretical departure points regarding social voicelessness, ritual spaces and the visibility of resistance. He also finds that in each of the dramas (like Krismis van Map Jacobs) there is an indication of passive and actual protest linked to the social and political conditions from which the works originated. This, Coetser says (2012: 60), can be viewed as 'reflections of real communities' experiences of displacement, homelessness and nostalgia'. Coetser continues by saying that resistance is not only embodied in these plays, but is also present in the methods that the playwright uses, for example the use of Kaaps. Coetser comes to the conclusion that Small as 
playwright is also present in his plays as 'invisible protest character'. Small's resistance is especially focused on the social issues in the community, issues with which he was involved in his career as social worker and later as professor of Social Work at the University of the Western Cape. He is an important voice in articulating the emotions of his people through his dramas and poetry. Through his works, he speaks on behalf of, but also through, his people about the liberal values of freedom of thought and speech (Willemse 2016).

The following section discusses the question whether the school curriculum should provide for Kaaps as language of instruction, with Krismis van Map Jacobs as focus.

\section{Students' experience of $M a p$ Jacobs}

As part of Afrikaans Curriculum Studies in the Faculty of Education at the University of Stellenbosch, the writer taught a module based on the text to fourth year B.Ed. students. The class also attended a production of the drama. Following on this, the students were requested to complete a questionnaire and eight students were interviewed on the issues covered in the play. The response of the students would give an indication of the relevance of the drama in the current context of the gang culture in the Cape. Although one cannot discount the Hawthorne effect - which indicates that the group fared better simply because of a change in routine (Mouton 2001:106) - the response of the students to the questionnaire and interviews can be summed up as follows:

The whole group, despite their diverse language backgrounds, indicated that they had enjoyed the play and that in fact they enjoyed doing 'something different from the usual dramas'. Most of them indicated that they did not have a problem with the Kaaps in which the play was written. Where they encountered strange words, they could look them up easily in the reading guide included with the drama (65-89), which led to good understanding. Only a few students indicated that they had struggled to understand the drama, although they were also helped by the Reading Guide and the glossary.

The whole class agreed that they considered the drama to be relevant, because gang activities are such a big problem in the Western Cape and affect the lives of so many people. Everyone was determined to also prescribe the drama for their students when they started to teach. No-one thought the drama or its language use was offensive. Most said, 'But this is how the gangs speak'.

The students agreed that solutions for gang violence are not easy, noting that even the government and the police are seeking answers. Half of the students went further than the solution provided in the drama (the church) and said that education and training was the only way out for township youth to escape from the 'prison'. But others pointed out that gangs in reality target the schools because they realize that good education will give the youth a different outlook. It is in the interest of gangs that schools should be dysfunctional. Given the poverty in which these people live, the church and their religion are for many the only way out. The group concluded that studying the drama Map Jacobs at school is one of the best (maybe the only) way to tackle the problem successfully. Religion can certainly play a role, but it could possibly shift the responsibility and the youth of today must learn from childhood at school to take responsibility for their own future. 
When Krismis van Map Jacobs was performed at Artscape in 2012, David Johnson who played the role of Map Jacobs, said the following to Mariana Malan (Die Burger, 27 July 2012) about the relevance of the drama in the current context:

I see the role as part of my social responsibility. Although the story of Map Jacobs was written in Kaaps, audiences in all parts of the country react enthusiastically and positively to this production of the drama prescribed for matric learners. It is necessary that this part of our history is remembered and that people who don't know it, are informed.

\section{Thirty years later}

What happened in 1983, when MapJacobs was written, unfortunately continues to this day, with gang violence continuing to plague the Cape Flats. The question can be asked whether this drama from 1983 is still valid as topical social comment on the gang culture of the Cape Flats. Related issues are to what extent Kaaps - the language in which Map Jacobs was written - is taken into account within the context of Standard Afrikaans and within the Curriculum Assessment and Policy Statement (CAPS), and whether the theme of Map Jacobs is still relevant as prescribed work for schools.

On the Cape Flats everyone knows of the gang war in neighbourhoods like Manenberg, Delft, Elsies River and Bonteheuwel, where it has become a way of life. It is voiced in newspaper headlines and placards on lamp posts. The warring gangs attack one another with such violence that police fear going into these areas. Over weekends there is shooting back and forth where the police are forced to use shock grenades in an attempt to stop the violence (Die Vryburger, 7 April 2015). Often it is innocent residents who must pay the highest price. Innocent children often die on the way to school in the hail of bullets between opposing gangs (Son, 26 January 2016). According to recent police statistics, Manenburg's murder rate has increased by more than $50 \%$, with 63 murders between April 2015 and March 2016. In September 2016 a total of 31 people died in the gang war in Delft, and in Elsies River 20 people died in one week, of which 14 died in one shooting incident (Son, 1 September 2016).

The principal of Manenberg Secondary School, Thurston Brown, who grew up with the violence and poverty in Bonteheuwel, says the following of the learners' experience of violence: 'It is as if it [violence] has become part of the children's psyche. It's sad because they become numb, and no longer get emotional about it' (Schoeman and Germishuys, 2016). Often schools have to be closed because it becomes too dangerous for children to leave their homes. This links to Willy la Guma's remark in this drama: 'They feel trapped in their small cages and cement strips and, like those in prison, have no prospects.' (50)

With an investigation into the gang culture, the first question is thus to what extent the curriculum must be adapted to make provision for these abnormal conditions. This goes especially for the CAPS which places a strong emphasis on interactive learning. This allows learners to deal with language (like Kaaps) in intra- and interpersonal ways. 


\section{A THEORETICAL FRAMEWORK: PRESCRIBED WORK IN KAAPS}

Shulman (1987: 9) points out that pedagogic content knowledge is more holistic than knowledge of a specific subject. It refers also to conceptual knowledge of a subject, which includes techniques and approaches like the use of a particular variety of the language of instruction to make it more accessible to learners. With this approach to language, the CAPS links to the theory of social constructivism and cognitive development as expounded by Lev Vygotsky (1978: 24-25). Social constructivism identifies two aspects of social context which are of importance here, namely (1) historic knowledge, such as the forced removals (cf. Le Cordeur $2016 \mathrm{~b}$ ) and (2) interaction with more knowledgeable adults. The premise of the social constructivist theory is that the learners construct knowledge and understanding by interaction with other learners, their immediate community, but also with themselves (Basson 2014: 112; Woolfolk 2010: 44). Meaningful learning only takes place if the learners interact with their context and culture, and when there is social contact with other learners and/or adults like parents and teachers, and if it is in a language (like Kaaps) understood fully by both parties. If the learners do not feel comfortable speaking in their home language in class, they will also be hesitant to participate in class discussions.

\section{KAAPS AS LANGUAGE OF INSTRUCTION}

As pointed out by Van Rensburg (2016), the roots of Kaaps are to be found almost 360 years ago, when speakers of different languages voluntarily or under compulsion got to know one another at the Cape and out of that contact a new language originated. As noted by Kotzé (pp.), Kaaps itself is not a homogeneous variety, and its socio-geographic variation is part the wealth of Kaaps as matrilect of Afrikaans.

By using Kaaps in a literary work like Krismis van MapJacobs, Small protests not only against the autonomous use of Standard Afrikaans, but also against those publishers who at that time ignored Coloured poets and writers if they wrote something in their home language (Kaaps). According to Willemse (2016) the speakers in Adam Small's Kaaps poems speak with an urgency and presence as never before experienced in Afrikaans literature. Through his work, Small exalted Kaaps to a fully-fledged language and gave it dignity (Willemse 2016). The question is now to what extent it should be utilised as language of instruction.

It is widely accepted that mothertongue instruction is indispensable in the first six years of a child's school career for cognitive development (Cummins 2005; Heugh 2006). If this is true of Afrikaans and English, then the same argument goes for Kaaps, the mother tongue of a few million speakers (Le Cordeur 2015). The differences between Standard Afrikaans and other varieties of Afrikaans meant that a large group of Afrikaans-speaking learners who grew up at home with Kaaps, had to do their schoolwork in Standard Afrikaans (Esterhuyse1986; Le Cordeur 2011).

The question here is whether Kaaps should be taken into account in the school curriculum so that the language of instruction makes a contribution to the academic success of learners who grew up with Kaaps, and if so, how this should be done. It is especially important 
because experts (Vilakazi 2002; Heugh 2006) agree that the language in which the curriculum is conveyed forms the core of South Africa's education crisis. If the medium of instruction in school is a language that is not spoken at home, the problems of learning together with dropouts increase dramatically (Mehrotra 1998:479).

The curriculum and the medium in which it is conveyed, is thus deeply interwoven with the institutional culture of schools. If school authorities continue to ignore language varieties, the institutional environment, of which the language of instruction is part, is not conducive to curriculum change or academic success (Le Cordeur 2016a).

Dyers (2016: 65) puts it best when she says:

The longer it takes to welcome the actual language repertoires of learners who speak Kaaps as home language to the classroom, the greater the estrangement and even hostility will be between these learners and standard Afrikaans.

This is especially true for the way Kaaps is treated on the Cape Flats, where the failure rate is high. Before learners can master the subject, they must first overcome the barrier to learning, i.e. the language of instruction (Heugh 2006). The CAPS requires that learners, irrespective of the socioeconomic background, physical or intellectual abilities, are equipped with the knowledge, skills and values required for self-fulfilment and meaningful participation in society as citizens of a free country, and to be sensitive to issues which reflect diversity, such as poverty, inequality, race, gender, language, age, disability and other factors (DBE 2012: 4).
CAPS also expects of learners to identify problems and solve them; to take decisions through creative thinking; to analyse information and evaluate it critically; and to make informed choices (DBE 2012: 8). In the context of the CAPS, language is also a cultural and aesthetic means by which people make sense of the world in which they live. The effective use of language makes it possible for learners to express their identity, feelings and ideas, to interact with one another and to manage the world they live in (DBE 2012: 8). These are cognitive skills of a higher order which can only be appropriated via the learner's home language: in this case Kaaps (Le Cordeur 2016a).

It is not argued that Standard Afrikaans should be replaced by Kaaps as language of instruction. Learners still need Standard Afrikaans for examinations and further study. But as indicated above, CAPS indeed provides for instruction in a variety like Kaaps. In the words of Hendricks (2016: 31): 'Kaaps is ... inextricably part of Afrikaans and there is an appeal to us to continue taking this fact into account seriously in the future, linguistically and normatively.'

According to Willemse (2016: 4), teachers ought therefore to be equipped with skills to appreciate and promote an awareness of the place and dignity of non-standardised Afrikaans varieties. Hendricks (2016: 30) further notes:

For Kaaps to flourish on the one hand as fully-fledged communication code beside Standard Afrikaans and on the other hand to be taken into account as fertile source for the standard variety, it must be withdrawn from its state of marginalisation. 
Where prescribed books previously portrayed a world with which learners with Kaaps as home language were not familiar, Kaaps can today be used effectively as literary language with Krismis van Map Jacobs as an appropriate example.

\section{IDENTITY}

In a UNESCO report (UNESCO 2000) the important role of language to express cultural diversity was emphasised. In this regard it is important to note that language is not only a medium of communication; it represents a wealth of cultural things and is bearer of identity, values and opinions. Language facilitates our experiences, our intellectual and cultural environments, and the ways in which we interact with people (UNESCO 2000).

Small articulates it this way: 'Kaaps is a language, a language in the sense that it carries the full fate and destiny of the people who speak it ...' (Small 1962). Willemse (2016) argues that it is Small whom everyone knows as the poet and playwright who penned the spoken language of the Cape working class so piercingly and ironically. According to Dyers (2016: 65) the often derogatory references to Kaaps are contrary to the linguistic reality that Kaaps is a continuum of varieties which all fall under Afrikaans. According to Willemse (2016) the language of the working class of the Cape has been associated with variances, stupidity and jocularity since the beginning of the nineteenth century. But Small elevated it to a fully-fledged language.

David Johnson, who portrayed Map Jacobs in Krismis van Map Jacobs when it was again staged at the Artscape theatre in 2012, refers to language as an identity marker: "The language in the piece is important to me. It is part of who I am' (Die Burger, 27 July 2012).

As one of the writers of the sixties (Sestigers), Small was part of a group of liberal voices in the Afrikaans literature. Yet as the only Coloured, he was still an outsider. By referring to Small as 'black Sestiger' (Dekker 1966: 292), his contribution to one of the richest periods of Afrikaans literature is acknowledged, but at the same time implies his marginalisation in the literature: a position of inside but also outside. With Krismis van Map Jacobs (1983), Small brings, according to Willemse (2012), the worlds of exclusion and displacement to the stage. In my view it is thus Small himself who confesses that he just wanted to "belong" somewhere. He does this in the words of Willy la Guma:

As jy 'n regte mens is, dan wil jy wiet waar jy aan is en waar jy af is, waar jy stáán. Understand? Jy moet tog iewers belong, belong! Somewhere moet jy darem iets kan identify moet jouselwers ... (51) [If you are a real person, then you want to know where you are on and where you are off, where you stand. Understand? You must surely, surely belong somewhere! Somewhere you must be able to identify something with yourself ...]

\section{CONGLUSION}

This paper investigated whether the drama of Krismis van Map Jacobs is still valid as socio-topical commentary on the gang culture reigning on the Cape Flats, taking as sub-questions: (a) to what extent Kaaps should be taken into account as language of instruction in the context of Standard Afrikaans and the CAPS curriculum and (b) whether the theme of Map Jacobs is still relevant as prescribed work within the CAPS. 
The study made it clear that a solution for the gang problem on the Cape Flats is not so simple. Studying the literary works of Small such as Krismis van Map Jacobs can make a contribution to understanding the complexity of the gang culture. Map's conversion to religion and the church indeed offers a solution which lead to a permanent change in the main character, but from the response of the students it was clear that good education, including studying good literature like Krismis van Map Jacobs, could also play a role in the healing process.

Secondly, Kaaps as language of instruction also has a role to play in the formal curriculum. This does not mean that Kaaps should serve as replacement for Standard Afrikaans, but given the respect and status that Kaaps enjoys on the Cape Flats, it is the ideal medium to convey the message of Map Jacobs to the youth of the Cape Flats. It was indeed Small who broke down the stigma around Kaaps by using it in Afrikaans literature (Van Wyk 2012).

Thirdly, the theme of Krismis van Map Jacobs is still as relevant today as it was in 1983 when the drama was written. It is about the lot of people caught up in a dismal existence due to factors beyond their control; people who were banned to the Cape Flats by apartheid laws and in the process lost their identity (50).

In a previous section it was pointed out that CAPS expects learners to be able to evaluate information critically and make informed choices (DBE 2012: 8). By studying the drama Krismis van Map Jacobs these goals are achieved. As gang leader Map is anything but stupid. He is rather a victim of his circumstances. In fact, the milieu in which he finds himself plays a role in the choices he makes, as becomes apparent in the following confession he makes to his mother:
I made matric, standard ten. I know Ma had high hopes for me. But there was no money to study further, and when I searched for a job, a good job, well it was all for whites only... Whites who wanted to give me a job as messenger!! (31).

Map however has to accept responsibility for his actions, by giving himself up to the police:

Toe hou ek my hande yt, vi' die boeie ... Ek het myself opgegie. Ek het getry om 'it ... soes 'n man te vat... (35) [Then I held out my hands for the handcuffs ... I gave myself up. I tried to take it ... like a man ...]

But it is also about forgiveness: Map Jacobs is a product of his environment. He tries to be a good person. But how do you escape from an environment where you can only go so far and no further? The message is that Map's life has changed $(7,30)$ by accepting God. Youths caught up in the gang culture need only look at Map Jacobs to learn from his mistakes.

In this way the hopeless existence and the incarceration in the township achieves new meaning. Every day is not Krismis, yet there is hope for all the Map Jacobses in our society.

\section{BIBLIOGRAPHY}

Afrika, Basil. 2015. Manenberg is sat vir gangs. Son. 26 January 2015 http:// www.son.co.za/Nuus/manenberg-is-sat-virgangs-20150126 [9 August 2017]

Afrika, Basil. 2016. Mense val soos vlieë op die Vlakte. Son. 31 August.

http://www.son.co.za/Nuus/Wes-Kaap/menseval-soos-vliee-op-die-vlakte-20160831/ [9 August 2017]

Basson, M. 2014. Effektiewe ondersteuning aan die Xhosa-moedertaalsprekers in 
Afrikaansmediumklasse. Per Linguam, 30(1): 109-26.

"Bendegeweld in Wes-Kaap nou vreesaanjaend." Die Vryburger. 7 April 2015. http://www.dievryburger. co.za/2015/04/bendegeweld-in-wes-kaapnou-vreesaanjaend/ [9 August 2017]

"Bendes regeer op die Kaapse vlakte". 2016. Son, 26 January.

Bernstein, Basil. 1990. The structuring of pedagogic discourse - Class, codes and control. London and New York: Billings and Sons.

Botha, Danie. 2015. Review: Krismis van Map Jacobs by Adam Small, performed at Artscape Arena. Litnet: 16 May.

Carstens Wannie A.M. and Le Cordeur, Michael.L.A. (eds.). 2016. Ons kom van vêr. Bruin mense se bydrae tot die ontwikkeling van Afrikaans. Tygervalley: Naledi.

Coetser, Johan. 2012. Voorstellings van verset in drie Adam Small-dramas: Kanna hy kô hystoe, Joanie Galant-hulle en Krismis van Map Jacobs. Adam Small 75. Tydskrif vir Letterkunde, 49 (1): 51-60.

Cummins, Jim. 2005. Affirming identity in multilingual classrooms. Educational Leadership, September, 38-43.

Dekker, Gerrit. 1966. Afrikaanse Literatuurgeskiedenis. Cape Town: Nasou.

Dyers, Charlyn. 2016. Konsepomwenteling in die Taalwetenskap: Implikasies vir die Studie van Kaaps (pp. 59-70), in Frank Hendricks and Charlyn Dyers (eds.) Kaaps in Fokus. Stellenbosch: Sun Media.

DBE (Department of Basic Education) 2012. Curriculum Assessment and Policy Statement (CAPS): Afrikaans Home Language Grade 10-12. Pretoria: Government Printer.

Esterhuyze, Jan. 1986. Taalapartheid en Skoolafrikaans. Emmarentia: Taurus.

Gerwel, Gert, Jakes. 2012. Language and silence: Persoonlike herinneringe aan Adam Small, die digter-intellektueel, in Hein Willemse and Steward van Wyk: Adam Small 75. Tydskrif vir Letterkunde, 49 (1): 15-18.

Heugh, Kathleen. 2006. Die prisma vertroebel: Taalonderrigbeleid geïnterpreteer in terme van kurrikulumverandering. Tydskrif vir Geesteswetenskappe, 46(2): 63-76.

Hendricks, Frank. 2016. Die aard en konteks van Kaaps: 'n Hedendaagse, Verledetydse en Toekomsperspektief (pp. 1-36), in F. Hendricks and C. Dyers, C. (eds.). Kaaps in Fokus. Stellenbosch: Sun Media.

Kotzé, Ernst. 2016. Die historiese dinamika van Kaaps - Toe en nou (pp. 37-48), in F. Hendricks and C. Dyers (eds.). Kaaps in Fokus. Stellenbosch: Sun Media.

Le Cordeur, Michael. 2011. Die variëteite van Afrikaans as draers van identiteit - 'n Sosiokulturele Perspektief. Tydskrif vir Geesteswetenskappe, 51 (4): 758-777.

Le Cordeur. Michael. 2014. 'n Kritiesanalitiese beskouing van bruin Afrikaanssprekendes se rol in die Afrikaanse media en Naspers, in L. Rabe (ed.). 'n Konstante revolusie: Naspers, Media24 en oorgange. Cape Town: Tafelberg.

Le Cordeur, Michael. 2015. Die Small weg. Die Burger, 10 December: 11.

Le Cordeur, Michael. 2016a. Kaaps: Tyd dat die taal van die Kaapse Vlakte in die formele skool verreken word (pp. 83-100), in F. Hendricks and C. Dyers (eds.). Kaaps in Fokus. Stellenbosch: Sun Media.

Le Cordeur, Michael. 2016b. Kanalla-dorp was "colourful". Die Burger, 11 February: 17.

Le Cordeur, Michael. 2016c. Daar word Kaaps gepraat in die hemel. Die Burger, 27 June: 10.

Le Cordeur, Michael. 2017. Die aktualiteit van Krismis van Map Jacobs, met verwysing na die tema van bendekultuur en Kaaps as onderrigtaal. In J van der Elst (ed.) Adam Small; Digter, denker,dramaturg; ' $n$ Huldingingsbundel, p. 181-198. Aanvanklik uitgegee deur Die Suid-Afrikaanse Akademie vir Wetenskap en Kuns, Pretoria. 978-1-48530864-5.

Malan, Mariana. 2012. Map Jacobs steeds relevant. Die Burger, 27 July: 5.

Mehrotra, Sanjay. 1998. Education for all: Policy lessons from high-achieving countries. UNICEF Staff Working Papers. New York: Unicef. 
Mouton, Johan. 2006. How to succeed in your master's and doctoral studies: A South African guide and resource book. Pretoria: Van Schaik Publishers.

Prins, Mike J. 1987. Die direktief as dramatiese taalhandeling in Krismis van Map Jacobs. Literator, (8) 3: 26-38.

Schoeman, Le Roux en George Germishuys. 2016. Manenberg: Waar die "bullets" nie name op het nie. Netwerk 24, 15 April. http://www.netwerk24.com/Nuus/ Algemeen/manenberg-waar-die-bulletsnie-name-op-het-nie-20160415 [9 August 2017]

Shulman, Lee, S. 1987. Knowledge and teaching: Foundations of a new reform. Harvard Educational Review, 57(1): 1-22.

Small, Adam. 1962. Kitaar my kruis. Cape Town: HAUM.

Small, Adam. 1983. Krismis van Map Jacobs, school edition. Cape Town: Tafelberg.

UNESCO. 2000. The use of vernacular languages in education, in J.A. Fishman (ed.) 2000.

Van den Bergh, Samantha. 2016.

Bendegeweld eis al meer as 20 sedert begin April. Netwerk24. 11 April. http:// www.netwerk24.com/Nuus/Misdaad/ bendegeweld-eis-al-meer-as-20-sedert-beginapril-20160410 [9 August 2017]

Van Rensburg, Christo. 2012. So kry ons Afrikaans. Pretoria: Protea Boekhuis.

Van Wyk, Steward. 2012. Adam Small verdien Hertzogprys. Die Burger, 26 March: 3.
Van Zyl, Wium. 2012. Retorika in Adam Small se "Kanna hy kô hystoe". Tydskrif vir Letterkunde, 49 (1): 40-50.

Vilakazi, Herbert. 2002. African indigenous knowledge and development policy. Indilinga: African Journal of Indigenous Knowledge Systems, 1:2.

Vygotsky, Lev S. 1978. Mind in society: The development of higher psychological processes. Cambridge, MA: Harvard University Press.

Willemse, Hein and Van Wyk, Steward. 2012. Foreword. Tydskrif vir Letterkunde, 49 (1): $1-9$.

Willemse, Hein. 2016. Soppangheid vir Kaaps: Mag, kreolisering en Kaapse Afrikaans (pp.71 - 82), in Frank Hendricks and Charlyn Dyers (eds.). Kaaps in Fokus. Stellenbosch: Sun Media.

Willemse, Hein. 2016. Die groot goed wat Adam Small ons gegee het. Die Burger, 27 June: 7.

Woolfolk Anita. 2010. Educational psychology. 11 th edition. New Jersey: Pearson Education.

Prof. Michael le Cordeur is head of the Department of Curriculum Studies in the Faculty of Education at Stellenbosch University 